\title{
Working Students in Higher Education: Challenges and Solutions
}

\author{
*Tumin ${ }^{1}$, Ahmad Faizuddin ${ }^{2}$, Firman Mansir ${ }^{3}$, Halim Purnomo ${ }^{4}$, Nurul Aisyah ${ }^{5}$ \\ 1,3,4,5 Universitas Muhammadiyah Yogyakarta, Jl. Brawijaya, Geblagan, Tamantirto, \\ Kasihan, Bantul, Central Java, Indonesia \\ ${ }^{2}$ International Islamic University Malaysia, Gombak Selangor Malaysia \\ *tumin@umy.ac.id
}

\begin{abstract}
The current study explores the experiences of working students, especially in higher learning institutions in coping with the challenges of working while studying. It is expected that the suggestions and recommendations from the study can improve working students' experiences to be successful in both working and studying.This qualitative research which documentation and interview had been used in order to collect data on the experiences of working students at the International Islamic University Malaysia. Some working students were purposively chosen and interviewed to know the challenges they faced and how they overcome the problems.The findings of the current study show that the informants fully understood the concept of working while studying and considered it as a financial necessity and self-improvement. The informants exposed several challenges of working students such as time constraints and commitment to their studies. Despite the challenges, the informants considered working while studying as a motivation to further develop themselves and acquire necessary skills for better employment.This study is important as many college students are working while enrolled in higher education. They may experience time constraints managing the responsibilities of both student and worker. Thus, it is significant to understand their experiences that may affect the future of their academic studies.This study provides some implications and recommendations for working students to overcome the challenges. They include time management, commitment, discipline, and responsibility.
\end{abstract}

Studi saat ini mengeksplorasi pengalaman mahasiswa yang bekerja, khususnya di perguruan tinggi dalam menghadapi tantangan bekerja sambil kuliah. Saran dan rekomendasi dari penelitian ini diharapkan dapat meningkatkan pengalaman kerja mahasiswa agar berhasil baik dalam bekerja maupun belajar. Penelitian kualitatif dengan dokumentasi dan wawancara ini digunakan untuk mengumpulkan data tentang pengalaman kerja mahasiswa di Internasional. Universitas Islam Malaysia. Beberapa mahasiswa yang bekerja sengaja dipilih dan diwawancara untuk mengetahui tantangan yang mereka hadapi dan bagaimana mereka mengatasi masalah tersebut. Temuan penelitian ini menunjukkan bahwa informan memahami sepenuhnya konsep bekerja sambil belajar dan menganggapnya sebagai kebutuhan finansial dan peningkatan diri. . Para informan memaparkan beberapa tantangan mahasiswa yang bekerja seperti kendala waktu dan komitmen untuk belajar. Terlepas dari tantangan tersebut, para informan 
menganggap bekerja sambil belajar sebagai motivasi untuk lebih mengembangkan diri dan memperoleh keterampilan yang diperlukan untuk pekerjaan yang lebih baik. Studi ini penting karena banyak mahasiswa yang bekerja selama mendaftar di pendidikan tinggi. Mereka mungkin mengalami kendala waktu dalam mengelola tanggung jawab siswa dan pekerja. Oleh karena itu, penting untuk memahami pengalaman mereka yang dapat mempengaruhi masa depan studi akademis mereka. Studi ini memberikan beberapa implikasi dan rekomendasi bagi mahasiswa yang bekerja untuk mengatasi tantangan tersebut. Itu termasuk manajemen waktu, komitmen, disiplin, dan tanggung jawab.

Keywords: Working Students, Working While Studying, Student's Experiences, International Islamic University Malaysia.

Received: March 20, 2020; Revised: June 3, 2020; Accepted: June 28, 2020

\section{INTRODUCTION}

Many students are working while enrolling in higher education (Bennet, McCarty \& Carter, 2015; Darolia, 2014). This employment somehow affects their academic studies and college experiences. Among the reasons why students choose to work while studying are due to increasing study cost, decreasing scholarship, and low family incomes. These situations have resulted in increasing number of students to do part-time employment and encourage the students who are willing to continue their studies to higher education to take loan (Metcalf, 2003; Watts \& Pickering, 2000). Even though there is a specific budget for education in the form of scholarship, it is indeed not the privilege for most of the students. Hence, loan is considered the best alternative for students to continue their studies (Lucas \& Lammont, 1998).

Some students might have to work full-time and do multiple jobs to cover the expenses of their studies (Goldrick-Rab, 2016). Although it is difficult to determine the exact numbers of working students, Curtis (2007) and Hakkinen (2006) described that between 50 and 60 per cent of university students are engaged in part-time employment. Full-time or part-time employment may alleviate the financial pressure of working students. However, they may face other problems such as time constrains and allocation to study. Additional responsibilities related to personal matters and family duties might add up to stress and mental health issues (Matheuws, 2018). Furthermore, the negative impacts of working students are mainly related to anxiety, depression, and poor academic achievement (Mounsey, Vandehey and Diekhoff, 2013).

Based on the above-mentioned explanation, the current study explores the experiences of working students, especially in higher learning institutions in coping with the challenges of working while studying. Hence, the aim of this research is to develop an understanding of working students amongst postgraduate students at the International Islamic University Malaysia, determine the reasons behind the choice of part-time employment, and find out the challenges and how the students overcome the problems. It is expected that the suggestions and recommendations from the study can improve working students' experiences to be successful in both working and studying (Ikhwan, 2018). 


\section{LITERATURE REVIEW}

\section{The Phenomenon of Working Students}

Darolia (2014) found that working students in higher education is a common phenomenon everywhere. Most research on working students focus on the examination of the effect of students' employment on academic outcomes such as grade point average and commitment to studies (Peterson, 2016; Scott-Clayton, 2011; Thibodeaux et al., 2017).

However, even though the number of working students is growing to a greater extent, this is not a new phenomenon. Over 30 years ago, working while studying was considered as a good preparation in one's later career (Steinberg et al., 1981; Schill, McCartin \& Meyer, 1985). In recent years, working whilst studying is considered necessary to develop the skills of teamwork, communication, and costumer care (Lucas \& Lammont, 1998; Curtis \& Lucas, 2001). According to Watts and Pickering (2000), working while studying has many positive outcomes to persist in the modern higher education realm.

In addition to the above studies, some researchers also focus on the time use by working students. As a consequence, the more time a student spends on working, the less time he or she engages in academic studies (Greene \& Maggs, 2015; 2017). Mathuews (2018) described that students' experiences of time constraints are normally related to the working time poor. On the other hand, the experiences of working parttime can enhance students' motivation in academic studies and employment prospects (Curtis \& Shani, 2002; Curtis \& Williams, 2002). Hence, students need a combination of academic knowledge and financial needs to enhance their future career opportunities (Harvey, 2000; Devlin, James \& Grigg, 2008; Nonis \& Hudson, 2006).

Working students can be categorized into two main groups: young working learners (age 16-29) and mature working learners (age 30-54). Regardless of race, female students are more likely to work while studying compared to their counterparts (Carnevale et al., 2015). Working while studying is an introduction to the real-world experience (Tymon, 2013; Tomlinson, 2007), thus the money earned from the employment was most of it spent on essential living expenses (Manthei \& Gilmore, 2005). For that reason, researchers suggested that higher education institutions should be more flexible and identify opportunities for work and career experiences (Yorke, 2004; Glover, Law \& Youngman, 2002).

\section{The Impacts of Working While Studying}

One of the primary reasons' students work while studying is to help pay for their college fees. On the other hand, financial aids do not sufficiently cover all college expenses (Mathuews, 2018). Institutional tuition discounts normally cover about 1220 per cent of college tuition and fees. With the increasing tuition fees, some students even cannot afford to pay with their saving money from their previous employment (Carnavale et al., 2015). Even though the college expenses are high, some students are still pursuing their degree to improve their standard of living through education (Pusser, 2010).

A variety of studies have studied the effects of students' employment on their academic studies. The negative impacts of working students are mainly related to 
anxiety, depression, and poor academic achievement (Mounsey, Vandehey and Diekhoff, 2013). Even though there is no proof for significant different on the academic performance, it was revealed that working students display more anxiety and depression compared to their counterparts. Most of the studies agreed that students who choose to work whilst studying at several point of time will suffer from stress and even leaves less desired time to study (Manthei \& Gilmore, 2005; Jogaratnam \& Buchanan, 2004).

In addition, working while studying also affects students' mental health. Many studies suggested that the biggest detrimental effect of student employment is mental health, which resulted in negative impact on academic performance (Hovdhaugen, 2015; Creed, French \& Hood, 2015; Darolia, 2014). Students might desire to achieve higher grades and attend lectures often, but it is not possible due to their working schedule (Curtis \& Shani, 2002). For that reason, universities should be flexible in accommodating such working students (Curtis, 2007) so they can acquire both academic success and enhance employability (Watts \& Pickering, 2000).

Mental health has become a big issue in higher education (Castillo \& Schwartz, 2013). Working students and mental health are closely related mainly due to financial stress that drives the students to work and study. Studies showed that financial stress contributes to decreased grades and levels of health (Bennet et al., 2015; Britt et al., 2016). Vaughn et al. (2016) acknowledged that employment might pull students away from their academic activities.

\section{METHOD}

This qualitative methodemploys semi-structured interviews in order to collect data as well as to investigate the experiences of postgraduate students of the International Islamic University Malaysia who are working whilst studying. Moreover, researcher also used a documentation to collect data such as book, journal and other documents which are suitable with this research. A qualitative studyhad beenemployed to explore more in-depth and abundant data for the research (Cresswell, 2012). Regarding Informants were chosen purposively amongst the postgraduate students who have more experience and knowledge about this problem. The first informant was coded as Arif and the second informant was coded as Zaki. The interviews were taped using a voice recorder and write downlater.

The information obtained from the informants were transcribed verbatim, words by words, to keep all evidence from missing and misinterpreted. Two trustworthy interraters were chosen to test and check the information generated from the interviews. This step is important to know the credibility and reliability towards the study. The two inter-raters were doctoral students in educational administration at international Islamic University Malaysia. They are given full transcripts and selected themes generating from the main ideas. Once the transcripts and the inter-raters were ready, the researcher then used a formula to determine the reliability of the information: number of agreements divided by total number of agreements plus disagreement. The result shows that the first rater gave 86.66 per cent and the second one gave full point 100 per cent. The total average of both raters is 91.66 per cent, which indicates a good reliability to confirm the study. 


\section{RESULT AND DISCUSSION}

\section{Students' Perceptions on Working while Studying}

Based on the responses from the informants, there are several driving forces of why student choose to work whilst studying. They are caused by financial support, selfdevelopment, and internal motivation to integrate theory and practice. From the responses, it can be inferred that the informants seemed to fully understand the motivation and reasons behind working while studying.

The informants have their own motivations to continue studying while working at university. According to Arif, he felt that he needs improving his quality of life. Thus, he decided to further his study even though he must work part-time. Meanwhile, Zaki opined that working while studying is just to get the experiences and additional financial support for him as a student.

The two informants were aware and fully understood the challenges and problems of working students. However, they still need to do it for the reasons they explained below:

"Theoretically, it is very good actually. But to integrate and do both at the same time, it is very difficult indeed" (Arif)

"I believe that education is important, but we also need money for studying. So, seeking money is also important" (Zaki)

They even can differentiate between students who are studying while working and students who are working while studying. According to Arif students who work while studying focus more on their study. For them, working is just to support their study. On the other hand, students who study while working focus more on working rather than studying. Thus, the end result might be different. Differently, Zaki explained that both kinds of students focus on working and studying to get the life experiences.

As the literature suggested, it is no surprise that Arif and Zaki are not alone in the practice of working while studying. The two informants explained:

"Yes, I have many friends who work while studying. It sometimes makes them have to be absent from the class and often the communication is done through email" (Arif)

"Yes, some of them work at formal sector and informal sector" (Zaki)

The main reasons why students are working while studying might be personal and subjective. Arif opined that he personally wanted to work to increase his skill. While Zaki viewed the practice of working while studying as getting a financial support. He personally wants to become independent and does not want to burden his parents in terms of paying tuition fees and expenses. On top of that, working while studying for Zaki can get him experiences of the real work in the real life.

\section{The Impacts of Working while Studying}

Overall, both informants felt happy they could manage their times doing both studying and working. Arif mentioned that he was happy and enjoys what he does. According to him, new experiences in working can help him to get new ideas when he has a problem. He specifically acquired problem solving skill. For Zaki, it means that he can 
manage time wisely and appreciate the importance of time when he studies and when he works.

Working while studying has both positive and negative impacts for students. As stated by the informants, the positive impacts include building good character, time management, and self-development.

"The positive impact is I can manage my time wisely. I can have more chance to get new ideas in order to enrich my knowledge" (Arif)

"Mainly I am getting experiences from outside the class, how the world works and how to be responsible to ourselves" (Zaki)

Furthermore, Arif expressed that he has more time to spend with his family, while Zaki said that it makes him stronger and independent. The most important thing for him is he can pay the tuition fees and fulfill his needs.

When the informants were asked to what extent do the benefits of working can help them in studying, they simply answered that it helps them a lot in attaining the target and self-development.

"I can manage my time well because I have the target, why? My study has a target. I cannot ignore with my target. The target that must be fulfilled like this time and there is time scale determined from my institution so that I cannot enjoy and neglect or has no target" (Arif)

"Actually, when we go out to work in the real world, we must be mentally ready to face the fact that working world is not same as educational world. There are a lot to learn and adapt so we should be well prepared" (Zaki)

The informants did not specifically reveal the negative effects of working whilst studying. However, the negative impacts of working whiles studying could be found in the challenges faced by the informants in the next sub-section.

\section{The Challenges of Working While Studying}

As many working students, the informants also face challenges when they work and study simultaneously. The findings revealed that there are some negative impacts of working while studying. For Arif, the practice of working while studying impacts his academic performance. While for Zaki, his main problem is time management.

"Of course, there are many negative impacts, especially in academic performance. When I work, for instance, I tend to focus on my working world so my stamina will be drained drastically so I cannot focus on study" (Arif)

"Depending on the situation. The bad thing is when we cannot manage our time efficiently; it will take a longer time to complete the study. I have to complete my draft of dissertation for several years" (Zaki)

In term of academic performance, both informants agreed that the result of their study depends greatly on the time they put onto it. If they put more time to study, they will get good result, and vice versa, they will get bad result when they put more time on work. Arif believed that he has no problem with both situations. Depending on his efforts to manage the time for studying, the result will suit him accordingly. Thus, Zaki agreed that the time for working and studying must be divided equally. 
When the informants were asked how they overcome the challenges, they answered that they usually do self-reflection and time management.

"The first thing that I usually do is self-reflection. It is important because sometimes the problems come from ourselves. We need to conquer ourselves first so we can manage our surrounding. Meaning to say that we have to be ready to face any challenges" (Arif)

"The main point is how we manage the time efficiently. In doing so, I believe that we must be healthy. I do exercise; balance the nutrient of food in order to be healthy so I will be able to manage my time fully" (Zaki)

\section{Some Suggestions to Improve Academic Performance}

Based on the discussion above, there are some suggestions for students who have a similar condition, i.e. working while studying. Among the suggestions are the students who decide to work while studying must be first of all committed and disciplined. They need to manage their time wisely because it is the most essential element in balancing the work and study at university (Ikhwan, 2017).

As both informants agreed, working while studying is not easy at all. Yet, it is doable and manageable as long as the person is responsible in what he or she is doing. Drawing upon the results of the interviews, the following are some suggestions and recommendations from the informants.

"The first thing to make clear is time management. Sometimes a person has objective A but when he divides his time it does not focus on A because the portion must be clear between working and studying. The second thing is a good reflection on ourselves because studying is not only to get the result or certificate, or we pass and get grade $A$ and $B$. The most important thing is what we get from the study. Reflection is very important to know the source of the problem from within ourselves" (Arif)

"My suggestion is that we must focus more on our studying and it is our main objective in seeking the knowledge, whereas working is just as an addition for experience and knowing the working world" (Zaki)

In addition, the two informants provided some views to improve student's performance when they have to work.

"Treat the time for studying like as the time for working. If you want to be successful in both working and studying, you must balance the time for both" (Arif)

"My suggestion for the students who work while studying is to appreciate your work and be professional. Consider that working is a process of learning in achieving a good life in the future. Do not forget that our main objective is first of all studying and it becomes our main basis" (Zaki)

\section{CONCLUSION}

The current study shows that some postgraduate students at the International Islamic University Malaysia are working while studying. Based on the information from two $\mathrm{Ph} . \mathrm{D}$ students, students who are working while studying mostly comprehend the meaning of working whilst studying and its effects. The findings of this study revealed 
some major factors of students choose to work while studying. Mainly the students opt to work while studying due to financial needs to support their daily needs and academic expenses. In addition, working whilst studying aims to improve themselves and seek real-world job experiences for the future.

The findings of the current study also show some positive and negative impacts of working while studying at university. Hence, the recommendations and suggestion for students who have to work while studying are to be disciplined, responsible, committed, and have great time managing.

Based on the findings and discussion, the current study draws some implications and recommendations for educational practices. For working students, many studies revealed that part-time employment does not significantly determine the academic performance. The most important things for the students who are working whilst studying is to be self-discipline, committed, and have good time management between working hours and academic loads. For lecturers, they must comprehend the actuallifecondition of their students and accommodate the time, because working students are common and necessary in today's life. For educational institutions, some clear regulations and requirements must be made to support working students. It could be accommodated through online class or even volunteering jobs. Finally, it is highly recommended to employ a mixed method and more participants for future research to have better results, implications, and understanding of the issue of working students.

\section{REFERENCES}

[1] Bennett, D., McCarty, C., \& Carter, S. (2015). The impact of financial stress on academicperformance in college economics courses. Academy of Educational LeadershipJournal, 19(3), 25-30.

[2] Darolia, R. (2014). Working (and studying) day and night: Heterogeneous effects of working on the academic performance of full-time and part-time students. Economics of Education Review, 38, 38-50.

[3] Metcalf, H. (2003). Increasing inequality in higher education: The role of termtime working. Oxford Review of Education, 29(3), 315-329.

[4] Watts, C., \& Pickering, A. (2000). Pay as you learn: Student employment and academic progress. Education+ Training, 42(3), 129-135.

[5] Lucas, R., \& Lammont, N. (1998). Combining Work and Study: An empirical study of full-time students in school, college and university*. Journal of Education and Work, 11(1), 41-56.

[6] Goldrick-Rab, S. (2016). Paying the price: College costs, financial aid, and the betrayalof the American dream. Chicago: University of Chicago Press.

[7] Häkkinen, I. (2006). Working while enrolled in a university: Does it pay?. Labour Economics, 13(2), 167-189.

[8] Matheuws, K. B. (2018). The working time-poor: Time poverty implications for working students' involvement. Doctoral Dissertation. USA: Ohio University.

[9] Darolia, R. (2014). Working (and studying) day and night: Heterogeneous effects of working on the academic performance of full-time and part-time students. Economics of Education Review, 38, 38-50. 
[10] Peterson, S. (2016). Community college student-parents: Priorities for persistence.Community College Journal of Research and Practice, 40(5), 370384.

[11] Scott-Clayton, J. (2011). The causal effect of federal work-study participation: Quasiexperimental evidence from West Virginia. Educational Evaluation and PolicyAnalysis, (4), 506.

[12] Thibodeaux, J., Deutsch, A., Kitsantas, A., \& Winsler, A. (2017). First-year college students' time use: Relations with self-regulation and GPA. Journal of AdvancedAcademics, 28(1), 5-27. https://doi.org/10.1177/1932202X16676860.

[13] Steinberg, L. D., Greenberger, E., Vaux, A., \& Ruggiero, M. (1981). Early Work Experience: Effects on Adolescent Occupational Socialization. Youth and Society, 12(4), 403-422.

[14] Schill, W. J., McCartin, R., \& Meyer, K. (1985). Youth Employment: Its relationship to academic and family variables. Journal of Vocational Behavior, 26(2), 155-163.

[15] Lucas, R., \& Lammont, N. (1998). Combining Work and Study: An empirical study of full-time students in school, college and university*. Journal of Education and Work, 11(1), 41-56.

[16] Curtis, S., \& Lucas, R. (2001). A coincidence of needs? Employers and full-time students. Employee Relations, 23(1), 38-54.

[17] Watts, C., \& Pickering, A. (2000). Pay as you learn: Student employment and academic progress. Education+ Training, 42(3), 129-135.

[18] Greene, K.M. \& Maggs, J.L. (2015). Revisiting the time trade-off hypothesis: Work, organized activities, and academics during college. Youth Adolescence, 44, 1623-1637.

[19] Greene, K. M., \& Maggs, J. L. (2017). Academic time during college: Associations with mood, tiredness, and binge drinking across days and semesters. Journal of Adolescence, 56, 24-33. https://doi.org/10.1016/j.adolescence.2016.12.001.

[20] Matheuws, K. B. (2018). The working time-poor: Time poverty implications for working students' involvement. Doctoral Dissertation. USA: Ohio University.

[21] Curtis, S., \& Shani, N. (2002). The effect of taking paid employment during term-time on students' academic studies. Journal of Further and Higher Education, 26(2), 129-138.

[22] Curtis, S., \& Williams, J. (2002). The reluctant workforce: Undergraduates' parttime employment. Education+ Training, 44(1), 5-10.

[23] Harvey, L. (2000). New realities: The relationship between higher education and employment. Tertiary Education \& Management, 6(1), 3-17.

[24] Ikhwan, A. (2017). Metode Simulasi Pembelajaran dalam Perspektif Islam. Istawa: Jurnal Pendidikan Islam, 2(2), 1-34. https://doi.org/10.24269/ijpi.v2i2.623 
[25] Ikhwan, A. (2018). Penerapan Manajemen Hubungan Sekolah dan Masyarakat dalam Perspektif Islam. Al-Hayat: Journal of Islamic Education, 2(1), 1-16. Retrieved from http://alhayat.or.id/index.php/alhayat/article/view/19

[26] Devlin, M., James, R., \& Grigg, G. (2008). Studying and working: A national study of student finances and student engagement. Tertiary Education and Management, 14(2), 111-122.

[27] Nonis, S. A., \& Hudson, G. I. (2006). Academic performance of college students: Influence of time spent studying and working. Journal of Education for Business, 81(3), 151-159.

[28] Carnevale, A.P, Smith, N., Melton, M., \& Price, E.W. (2015). Learning while earning: The new normal. Georgetown University Center on Education and the Workforce. Retrieved from https://cew.georgetown.edu/wpcontent/uploads/Working-Learners-Report.pdf.

[29] Tymon, A. (2013). The student perspective on employability. Studies in Higher Education, 38(6), 841-856.

[30] Tomlinson, M. (2007). Graduate employability and student attitudes and orientations to the labour market. Journal of Education and Work, 20(4), 285304.

[31] Manthei, R. J., \& Gilmore, A. (2005). The effect of paid employment on university students' lives. Education+ Training, 47(3), 202-215.

[32] Yorke, M. (2004). Employability in the undergraduate curriculum: Some student perspectives. European Journal of Education, 39(4), 409-427.

[33] Glover, D., Law, S., \& Youngman, A. (2002). Graduateness and Employability: Student perceptions of the personal outcomes of university education. Research in Post-Compulsory Education, 7(3), 293-306.

[34] Matheuws, K. B. (2018). The working time-poor: Time poverty implications for working students' involvement. Doctoral Dissertation. USA: Ohio University.

[35] Carnevale, A.P, Smith, N., Melton, M., \& Price, E.W. (2015). Learning while earning: The new normal. Georgetown University Center on Education and the Workforce. Retrieved from https://cew.georgetown.edu/wpcontent/uploads/Working-Learners-Report.pdf.

[36] Pusser, B. (2010). Of a mind to labor: Reconceptualizing student work and higher education. In Perna L.W. (Ed.). Understanding the Working College Student: New Research and its Implications for Policy and Practice. Sterling, VA: Stylus.

[37] Mounsey, R., Vandehey, M., \& Diekhoff, G. (2013). Working and non-working university students: Anxiety, depression, and grade point average. College Student Journal, 47(2), 379-389.

[38] Manthei, R. J., \& Gilmore, A. (2005). The effect of paid employment on university students' lives. Education+ Training, 47(3), 202-215.

[39] Jogaratnam, G., \& Buchanan, P. (2004). Balancing the demands of school and work: Stress and employed hospitality students. International Journal of Contemporary Hospitality Management, 16(4), 237-245. 
[40] Hovdhaugen, E. (2015). Working while studying: The impact of term-time employment on dropout rates. Journal of Education and Work, 28(6), 631-651.

[41] Creed, P. A., French, J., \& Hood, M. (2015). Working while studying at university: The relationship between work benefits and demands and engagement and well-being. Journal of Vocational Behavior, 86, 48-57.

[42] Darolia, R. (2014). Working (and studying) day and night: Heterogeneous effects of working on the academic performance of full-time and part-time students. Economics of Education Review, 38, 38-50.

[43] Curtis, S., \& Shani, N. (2002). The effect of taking paid employment during term-time on students' academic studies. Journal of Further and Higher Education, 26(2), 129-138.

[44] Curtis, S. (2007). Students' perceptions of the effects of term-time paid employment. Education+ Training, 49(5), 380-390.

[45] Watts, C., \& Pickering, A. (2000). Pay as you learn: Student employment and academic progress. Education+ Training, 42(3), 129-135.

[46] Castillo, L.G., \& Schwartz, S.J. (2013). Introduction to the special issues on college student mental health. Journal of Clinical of Psychology, 69(4), 291-297.

[47] Bennett, D., McCarty, C., \& Carter, S. (2015). The impact of financial stress on academic performance in college economics courses. Academy of Educational LeadershipJournal, 19(3), 25-30.

[48] Britt, S.L., Mendiola, M.R., Schink, G.H., Tibbetts, R.H., \& Jones, S.H. (2016). Financial stress, coping strategy, and academic achievement in college students. Journal of Financial Counseling and Planning, 27(2), 172-183.

[49] Vaughn, A.A., Drake, R.R., \& Haydock, S. (2016). College student mental health and quality of workplace relationships. Journal of American College Health, 64(1),26-37.

[50] Cresswell, J. W. (2012). Educational Research. USA: Person Education. 